\title{
Energy Dispersive X-Ray Fluorescence Spectrometry of Major Tissues of Silky Fowls
}

\author{
Akitoshi NOZAKI and Takashi MAKITA \\ Department of Veterinary Anatomy, Faculty of Agriculture, Yamaguchi University, 1677-1 Yoshida, Yamaguchi 753, Japan
}

(Received 26 August 1997/Accepted 5 December 1997)

ABSTRACT. This report is to survey elements in frozen or freeze-dried samples of major organs of silky fowls with energy dispersive X-ray fluorescence spectrometer (EDXRF). There was not essential difference between frozen and freeze-dried samples. Of major elements, P, $\mathrm{S}, \mathrm{K}$, and $\mathrm{Cl}$ were always detected and $\mathrm{Mn}, \mathrm{Fe}, \mathrm{Ca}$, and $\mathrm{Zn}$ were detectable in certain organs. Iodine was detected in thyroid glands. Occasionally Br was detected. The duration of freeze drying, $24 \mathrm{hr}$ or 7 days, did not make significant difference in elemental analysis. — KEY WORDS: energy dispersive X-ray fluorescence spectrometer (EDXRF), freeze-dried sample, frozen sample, silky fowl, zinc content. J. Vet. Med. Sci. 60(4): 485-488, 1998

X-ray microanalysis and energy loss spectroscopy of ultrathin sections of biological sample have been limited in number and most of results so far published are only encouraging because of limited amount of elements in a section of $40-60 \mathrm{~nm}$ and also of dislocation of elements during specimen preparation including fixation, dehydration and embedding. Therefore, even Fe in red blood cell or I in thyroid gland is often failed to evaluate. Some attempts have been conducted to detect elements in bulk specimen with combination of scanning electron microscope (SEM) and X-ray microanalyser. Again dehydration and metallic and carbon coating of specimen required to SEM interfere the efficiency of elemental analysis.

Analysis of frozen or freeze-dried samples with X-ray spectrometry is another choice of approaches. This report is a trial to detect elements in biological specimen and to compare the efficiency of frozen and the freeze dried samples in their elemental detection.

Further to our previous reports on silky fowls [6, 8], Xray microanalysis [4] and energy loss spectrometry [1, 7, 9] of their pigment granules, this report surveys major elements in frozen or freeze-dried tissues from silky fowls with the energy dispersive X-ray fluorescence spectrometer (EDXRF) [10]. Silky fowls are Chinese origin and their feather is silky touch. Their almost all organs contain specific granules. This is not biocondensation of elements in those organs but specific distribution of pigments in connective tissue. Meat, blood, and egg of this fowl have been evaluated as healthy food or medicine. Metallic elements might contribute the effect.

\section{MATERIALS AND METHODS}

A total of 6 silky fowls (three females and three males) were used in this study. Tissue blocks from each organ were either freeze dried or simply frozen. Frozen samples were taken from the following 33 tissue blocks: feather, egg shell, shell membrane, yolk, egg white, blood, liver, kidney, pancreas, spleen, cardiac muscle (atrium), cardiac muscle (ventricle), lung, adrenal gland, eye ball, lens, retina, esophagus, crop, duodenum, jejunoileum, bone marrow, cerebrum, cerebellum, thyroid gland, chick comb, trachea, breast skin, testis, M. pectralis major, M. sartorius, femur and gizzard. Freeze dried samples were taken from the liver, kidney, pancreas, spleen, cardiac muscle (ventricle), lung, proventriculus, and gizzard. Freeze drying was conducted for $24 \mathrm{hr}$ or 7 days. The size of each tissue was variable but approximately same size of a given organ in both frozen and freeze drying samples for comparison.

Operating conditions of the energy dispersive fluorescence spectrometer (element analyser JSX-3300ED, JEOL, Tokyo) were $20 \mathrm{kV}, 15 \mu \mathrm{A}, \mathrm{Rh}$ target with $\mathrm{Si}$ (Li) semiconductor detector. Vacuum condition of specimen chamber was $10^{-2}$ Torr. For semi-quantitative analysis, the fundamental parameter method (standard less method) was employed. Results were analysed under the assumption that elements are in the form of oxidative compounds or carbon compounds in this instrument because it was programmed in this EDXRF. They were calculated as weight \%, but when the amount of a given element was very small it was recorded as parts per million (ppm).

\section{RESULTS}

Major elements in all tissues examined were $\mathrm{P}, \mathrm{S}, \mathrm{K}$, and $\mathrm{Cl}, \mathrm{Fe}, \mathrm{Ca}, \mathrm{Mn}, \mathrm{Zn}$, and occasionally $\mathrm{Br}$ were also detectable, though their amount was less than $\mathrm{P}, \mathrm{S}, \mathrm{K}$, and $\mathrm{Cl}$ (Table 1). In the thyroid glands, iodine was the characteristic element (Fig. 1).

There were no essential differences in the elements of the frozen samples (Table 1) and those of the freeze-dried samples (Tables 2 and 3). The duration of freeze drying, 24 hr or 7 days, did not make a significant difference in elemental analysis. Therefore, $24 \mathrm{hr}$ was sufficient in this survey. There was no difference in elements of male and female silky fowls.

\section{DISCUSSION}

Although not found in the high amount, $\mathrm{Zn}$ in almost all 


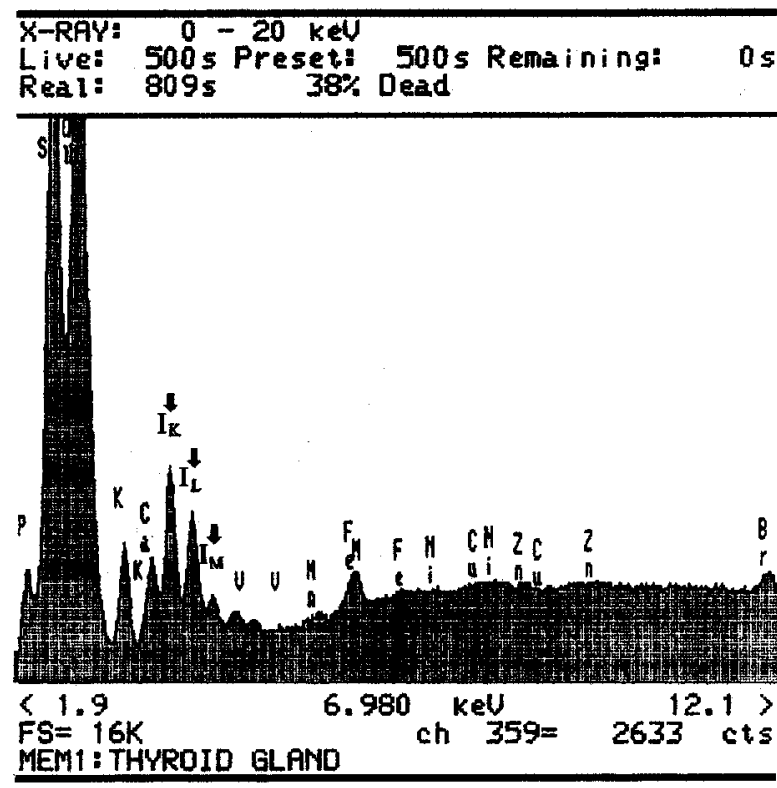

Fig. 1. Elemental analysis of frozen thyroid. Thyroid glands contain iodine (arrows). samples was characteristic to the silky fowl. $\mathrm{Zn}$ is detectable in oyster, eels, terrapin, and other Chinese medicines [11]. The silky fowl is also sometimes used as a material substance in Chinese medicine. Analysis of one Chinese medicine made of the tissues of silky fowls, Wuchi Paifeng Wan, detected P $(0.958 \%), \mathrm{Fe}(0.0357 \%), \mathrm{Ca}(0.0447 \%)$, $\mathrm{Mg}(0.0628 \%), \mathrm{S}(0.71 \%), \mathrm{Cu}$ (10.8ppm), Zn (107ppm), and $\mathrm{Mn}(6.13 \mathrm{ppm})$ [personal communication].

Electron energy loss spectrometry (EELS) of pigment granules in the skin of silky fowls also detected $\mathrm{Zn}$ and $\mathrm{Ca}$ $[1,7,9]$.

The major elements $\mathrm{P}, \mathrm{S}, \mathrm{K}$, and $\mathrm{Cl}$ were also detected by the wet scanning electron microscope (WET-SEM) in hydrated specimens $[3,5]$.

The overall elemental analysis employed in this survey is versatile in estimating approximate amounts of elements in frozen or freeze-dried samples. There are two types of element analyser: energy dispersive (as used in this survey) and wave length dispersive. The later type is more sensitive but requires electrons in the amount of hundreds or thousands times for fluorescent X-ray images. Therefore, the energy dispersive type is preferred for biological specimens.

Table 1. Elemental analysis of hydrated frozen tissues of silky fowls detected with EDXRF

\begin{tabular}{|c|c|c|c|c|c|c|c|c|c|}
\hline & $\mathrm{Na}$ & $\mathrm{P}$ & $\mathrm{S}$ & $\mathrm{Cl}$ & $\mathrm{K}$ & $\mathrm{Ca}$ & $\mathrm{Mn}$ & $\mathrm{Fe}$ & $\mathrm{Zn}$ \\
\hline Feather & $<5.99 *$ a) & 1.07 & 25.60 & 4.35 & 10.10 & 9.69 & 0.11 & 0.34 & 0.12 \\
\hline Egg shell & $<2.62 *$ & 3.81 & 1.30 & n.d. & 0.16 & 60.60 & $<119$ ppm* & $139 \mathrm{ppm}$ & n.d. \\
\hline Shell membrane & $<6.28 *$ & 0.91 & 21.60 & 11.50 & 15.50 & 2.74 & $<453$ ppm* & $531 \mathrm{ppm}$ & n.d. \\
\hline Yolk & n.d. ${ }^{\text {b) }}$ & 16.20 & 8.85 & 6.35 & 9.07 & 14.60 & $<612$ ppm* & 0.67 & 0.32 \\
\hline Egg white & n.d. & 1.05 & 15.80 & 17.70 & 27.60 & 1.90 & $<665 \mathrm{ppm}^{*}$ & 0.14 & n.d. \\
\hline Blood & n.d. & 3.39 & 9.84 & 28.70 & 20.90 & 1.97 & $<475$ ppm* & 3.13 & $346 \mathrm{ppm}$ \\
\hline Liver & n.d. & 12.70 & 12.40 & 3.25 & 25.90 & 1.18 & 0.13 & 1.22 & 0.40 \\
\hline Kidney & 8.21 & 11.20 & 9.84 & 9.82 & 19.20 & 1.23 & $528 \mathrm{ppm}$ & 0.77 & 0.14 \\
\hline Pancreas & $<4.90 *$ & 15.70 & 8.39 & 5.64 & 24.47 & 1.43 & $741 \mathrm{ppm}$ & 0.19 & 0.17 \\
\hline Spleen & n.d. & 9.57 & 16.30 & n.d. & 22.60 & 2.57 & $<0.15^{*}$ & 3.19 & 0.27 \\
\hline Atrium & n.d. & 9.23 & 14.30 & 5.40 & 26.90 & 1.60 & 998 ppm & 0.74 & 0.29 \\
\hline Ventricle & $<7.97^{*}$ & 8.65 & 13.30 & 5.11 & 27.30 & 1.71 & $<719$ ppm* & 0.79 & 0.35 \\
\hline Lung & $<5.11^{*}$ & 8.80 & 9.77 & 12.30 & 25.70 & 1.64 & $<484$ ppm* & 2.37 & 0.11 \\
\hline Adrenal glands & n.d. & 16.90 & 11.70 & $<1.55^{*}$ & 17.70 & 5.62 & $<0.17^{*}$ & 0.69 & 0.15 \\
\hline Eye ball & $<4.64 *$ & 4.07 & 5.09 & 29.00 & 12.50 & 18.60 & $<291$ ppm* & $920 \mathrm{ppm}$ & $481 \mathrm{ppm}$ \\
\hline Lens & $<9.95^{*}$ & 3.94 & 4.63 & 42.80 & 6.55 & 4.10 & $<419$ ppm* & $575 \mathrm{ppm}$ & n.d. \\
\hline Retina & n.d. & 6.53 & 4.55 & 8.26 & 3.91 & 41.80 & $<417 \mathrm{ppm}^{*}$ & 0.17 & $521 \mathrm{ppm}$ \\
\hline Esophagus & n.d. & 8.81 & 16.20 & 1.86 & 22.90 & 5.14 & $<0.12$ & 0.54 & 0.40 \\
\hline Crop & n.d. & 6.80 & 11.30 & 14.00 & 29.10 & 2.35 & $<591 \mathrm{ppm}^{*}$ & 0.32 & 0.19 \\
\hline Duodenum & $<7.06^{*}$ & 9.74 & 13.80 & 5.35 & 19.10 & 4.52 & 892 ppm & 0.48 & 0.26 \\
\hline Jejunoileum & $<22.6^{*}$ & 10.70 & 14.90 & n.d. & 15.10 & 3.70 & $<0.30^{*}$ & 1.20 & 0.29 \\
\hline Bone marrow & n.d. & 10.60 & 11.00 & 5.09 & 22.50 & 6.60 & $<982$ ppm* & 3.43 & $<808$ ppm* \\
\hline Cerebrum & $<5.75^{*}$ & 14.90 & 9.33 & 3.72 & 25.90 & 1.11 & 637 ppm & 0.30 & 409 ppm \\
\hline Cerebellum & $<5.81 *$ & 15.00 & 9.14 & 3.44 & 24.90 & 1.09 & $745 \mathrm{ppm}$ & 0.29 & $866 \mathrm{ppm}$ \\
\hline Thyroid glands & 24.90 & 8.00 & 12.10 & n.d. & 7.43 & 4.35 & $<0.22 \mathrm{ppm}^{*}$ & 0.76 & $<0.18^{*}$ \\
\hline Chick comb & $<14.6^{*}$ & 5.49 & 14.80 & 13.20 & 13.30 & 6.92 & $<0.13^{*}$ & 0.61 & $<0.13^{*}$ \\
\hline Trachea & $<7.15^{*}$ & 7.96 & 14.30 & 11.30 & 11.60 & 8.00 & $649 \mathrm{ppm}$ & 0.27 & 907 ppm \\
\hline Breast skin & $<8.61 *$ & 4.54 & 13.20 & 14.90 & 17.70 & 2.55 & $<853$ ppm* & 0.33 & 0.22 \\
\hline Testis & $<5.43^{*}$ & 12.20 & 9.40 & 8.64 & 26.40 & 1.29 & $<480$ ppm* & 0.17 & 0.14 \\
\hline M. pectralis major & n.d. & 11.30 & 10.10 & n.d. & 37.50 & 1.50 & $<0.11^{*}$ & 0.20 & $<965 \mathrm{ppm}^{*}$ \\
\hline M. sartorius & n.d. & 9.88 & 13.40 & 2.59 & 31.80 & 0.87 & $<699$ ppm* & 0.34 & 0.21 \\
\hline Femur & $<11.7^{*}$ & 9.30 & 6.34 & 1.55 & 2.65 & 33.60 & $<643$ ppm* & 0.19 & $<604 \mathrm{ppm}^{*}$ \\
\hline Gizzard & n.d. & 9.45 & 9.92 & 11.60 & 27.30 & 3.30 & $<764$ ppm* & 0.47 & 0.15 \\
\hline
\end{tabular}

a)*: deviation $2 \sigma$. b) n.d.: not detectable; cncentration: weight $\%$ or ppm. 
Table 2. Comparison of elemental analysis of 7 days or $24 \mathrm{hr}$ freeze-dried samples of silky fowls detected with EDXRF

\begin{tabular}{llcccccccc}
\hline & & $\mathrm{P}$ & $\mathrm{S}$ & $\mathrm{Cl}$ & $\mathrm{K}$ & $\mathrm{Ca}$ & $\mathrm{Fe}$ & $\mathrm{Zn}$ & $\mathrm{Br}$ \\
\hline \multirow{2}{*}{ Liver } & 7 days & 12.80 & 12.61 & 3.82 & 23.17 & 0.97 & 1.45 & 0.38 & $995 \mathrm{ppm}$ \\
& 24 hr & 11.67 & 12.36 & 3.48 & 25.17 & 1.50 & 1.39 & 0.21 & 0.10 \\
Kidney & 7 days & 11.64 & 10.31 & 7.45 & 25.60 & 2.79 & 1.03 & 0.30 & $893 \mathrm{ppm}$ \\
& $24 \mathrm{hr}$ & 10.56 & 10.80 & 7.41 & 27.42 & 2.35 & 1.55 & 0.31 & 0.36 \\
Ventricle & 7 days & 8.92 & 12.91 & 6.82 & 28.42 & 1.49 & 0.73 & 0.17 & $664 \mathrm{ppm}$ \\
& 24 hrs & 7.69 & 12.78 & 6.97 & 29.89 & 2.47 & 0.97 & 0.19 & 0.34 \\
Spleen & 7 days & 11.86 & 10.17 & 5.67 & 29.05 & 0.67 & 2.64 & 0.11 & $609 \mathrm{ppm}$ \\
& 24 hr & 12.14 & 10.39 & 4.77 & 28.89 & 1.23 & 1.89 & 0.13 & 0.14 \\
Pancreas & $7 \mathrm{days}$ & 14.48 & 8.98 & 5.70 & 24.70 & 3.46 & 0.29 & 0.33 & $533 \mathrm{ppm}$ \\
& $24 \mathrm{hr}$ & 15.19 & 10.59 & 2.20 & 24.80 & 3.18 & 0.74 & 0.21 & 0.19 \\
\hline
\end{tabular}

concentration: weight $\%$ or ppm.

Table 3. Comparison of elemental analysis of frozen and freeze-dried samples

\begin{tabular}{|c|c|c|c|c|c|c|c|c|c|}
\hline & & $\mathrm{P}$ & $\mathrm{S}$ & $\mathrm{Cl}$ & $\mathrm{K}$ & $\mathrm{Ca}$ & $\mathrm{Fe}$ & $\mathrm{Zn}$ & $\mathrm{Br}$ \\
\hline \multirow[t]{3}{*}{ Lung } & $1^{\text {a) }}$ & 8.80 & 9.77 & 12.30 & 25.70 & 1.64 & 2.37 & 0.11 & n.d. ${ }^{\text {d) }}$ \\
\hline & $2^{b)}$ & 8.42 & 10.57 & 13.65 & 25.93 & 1.98 & 2.30 & $824 \mathrm{ppm}$ & 0.16 \\
\hline & $3^{c)}$ & 10.83 & 13.58 & 17.68 & 33.97 & 2.62 & 3.07 & 0.11 & 0.21 \\
\hline \multirow[t]{3}{*}{ Trachea } & 1 & 7.96 & 14.30 & 11.30 & 11.60 & 8.00 & 0.27 & 907 ppm & $640 \mathrm{ppm}$ \\
\hline & 2 & 7.88 & 15.35 & 7.92 & 15.72 & 6.51 & 0.46 & $1000 \mathrm{ppm}$ & 0.14 \\
\hline & 3 & 10.44 & 20.65 & 10.72 & 21.92 & 9.37 & 0.67 & 0.15 & 0.21 \\
\hline \multirow[t]{3}{*}{ Esophagus } & 1 & 8.81 & 16.20 & 1.86 & 22.90 & 5.14 & 0.54 & 0.40 & n.d. \\
\hline & 2 & 7.13 & 12.48 & 11.50 & 26.68 & 3.70 & 0.31 & 0.14 & 0.18 \\
\hline & 3 & 9.30 & 16.12 & 14.82 & 35.23 & 5.01 & 0.42 & 0.19 & 0.25 \\
\hline \multirow[t]{3}{*}{ Duodenum } & 1 & 9.74 & 13.80 & 5.35 & 19.10 & 4.52 & 0.48 & 0.26 & n.d. \\
\hline & 2 & 9.93 & 11.54 & 4.75 & 26.11 & 6.83 & 0.58 & 0.20 & 0.12 \\
\hline & 3 & 12.95 & 15.13 & 6.11 & 35.03 & 9.45 & 0.81 & 0.28 & 0.17 \\
\hline \multirow[t]{3}{*}{ Jejunoileum } & 1 & 10.70 & 14.90 & n.d. & 15.10 & 3.70 & 1.20 & 0.29 & n.d. \\
\hline & 2 & 7.11 & 13.05 & 5.40 & 27.00 & 6.47 & 0.46 & 0.26 & 0.14 \\
\hline & 3 & 9.24 & 17.03 & 7.00 & 36.08 & 8.85 & 0.63 & 0.35 & 0.20 \\
\hline
\end{tabular}

a) Frozen sample, b) Freeze dried sample, c) Freeze dried sample, d) n.d.: not detectable; concentration: weight $\%$ or ppm.

However, the wave-length dispersive element analyser should be reevaluated when using bulk frozen or freeze dried specimen as samples because they can resist considerably strong electron beams.

A combination of the present analyser (EDXRF) and the scanning electron microscope, especially the WET-SEM and the environmental SEM (ESEM) [2, 3, 5], is available. The wave length dispersive type (WDXRF) used in concert with the electron microscope is also available.

Elements in 33 frozen tissues of silky fowls were analysed with an energy dispersive X-ray fluorescence spectrometer. Also analysed were elements in 5 tissues freeze-dried for 24 hr or 7 days.

Major elements detected were $\mathrm{P}, \mathrm{S}, \mathrm{Cl}$, and $\mathrm{K}$. $\mathrm{Ca}, \mathrm{Fe}$, $\mathrm{Mn}$, and $\mathrm{Zn}$ were also detectable but minor elements. Comparisons of frozen and freeze-dried samples and also comparisons between tissues freeze-dried for $24 \mathrm{hr}$ and 7 days did not find essential differences.

ACKNOWLEDGEMENT. We appreciate technical assistance and advice of Dr. Hitoshi Miura at JEOL.

\section{REFERENCES}

1. Kanaya, E. and Makita, T. 1995. Electron energy loss spectrometry of elements in pigment granules of silky fowl. p.35. 120th Annual meeting of Japanese Society of Veterinary Science (Abstr. in Japanese).

2. Makita, T. 1995. New microscopes and new tools of morphology in biomedical fields. Yamaguchi J. Vet. Med. 22 : $1-14$.

3. Makita, T. 1987. Applications of WET-SEM to biomedical samples. Yamaguchi J. Vet. Med. 14 : 1-16.

4. Makita, T. 1986. Electron microscopy and X-ray microanalysis of the pigment cells in skin and several organs of the silky fowl. pp.61-62. Proc. X VI Cong. Europian Association of Veterinary Anatomists (Budapest).

5. Makita, T. and Asahina, T. 1990. Comparison of WET-SEM and Environmental-SEM. Biomed. Scan. Electr. Microsc. 19 :35-37.

6. Makita, T. and Mochizuki, S. 1984. Distribution of pigment cells in tissues of silky fowl. I . Light microscopic observations. Yamaguchi J. Vet. Med. $11:$ 17-38.

7. Makita, T. and Oikawa, T. 1996. Element analysis of routinely fixed and embedded pigment granules of silky fowl 
with $200 \mathrm{kv}$ field emission EELS electron microscope. p.159. 52nd Japanese Electron Microscopy Society (Abstr.).

8. Makita, T. and Tsuzuki, Y. 1986. Distribution of pigment cells in tissues of silky fowl. II. Embryological survey. Yamaguchi J. Vet. Med. 13 : 11-20.

9. Makita, T., Tsuzuki, Y. and Manba, K. 1987. Detection of Ca in granules of pigment cells with energy loss spectrometer (EELS). p.480. Acta Anat. Nippon (Abstr.).
10. Nozaki, A., Kojima, N., Kanaya, E. and Makita, T. 1991. Energy dispersive X-ray fluorescence spectrometry of freeze dried 8 organs of silky fowl. p.47. 111th Annual meeting of Japanese Society of Veterinary Science (Abstr. in Japanese).

11. The Science and Technology Agency, Resource Survey Committee. 1983. Standard Tables of Food Composition in Japan, 4th ed. (Kagawa, A. ed.), Kagawa Nutrition University Press, Tokyo (in Japanese). 